\title{
Molecular Barcoding of Melissa Officinalis L. (Badranjboye) in Iran and Identification of Adulteration in Its Medicinal Services
}

Fahimeh Koohdar ( $\nabla$ f_koohdar@yahoo.com )

Shahid Beheshti University

Masoud Sheidai

Shahid Beheshti University

\section{Research Article}

Keywords: Melissa officinalis, DNA barcoding, ITS, cp-DNA

Posted Date: October 14th, 2021

DOI: https://doi.org/10.21203/rs.3.rs-944116/v1

License: (c) (i) This work is licensed under a Creative Commons Attribution 4.0 International License. Read Full License 


\section{Abstract}

Medication plants are an important source of disease treatment in many countries. Today, quality control of the products of medicinal plants is a major task. Customer health may be at risk due to fraud and misconduct in the sales associates ' sales centres. Melissa officinalis (Badranjboye) is an important medicinal plant in Iran used for several diseases. In Iran, the species of Dracocephalum, Hymencrater, Nepeta and Stachys are mistakenly sold under the name of badranjboye in the selling centers of medicinal plants that have different pharmaceuticals properties. To avoid this mistake, we will follow the following goals in this research: 1 - Check the cheating and identification of badranjboye in the Iran market of medicinal plants and 2 - Provision of molecular barcode for the medicinal species of Melissa officinalis. We compared the plant samples sold (leaf) and reference species with morphological properties, odor, and molecular sequences and performed various molecular analyzes, such as sequencing, genetic distance determination, and phylogenetic tree construction. The reports indicated that internal transcribed spacer (ITS) and psbA-trnH intergenic spacer (psbA-trnH) sequences are an efficient molecular marker to produce barcode gap and differentiating Melissa officinalis from other species.

\section{Introduction}

In the present century, it is important to recognize and adopt appropriate humane treatment methods against the dangers of human health, such as the dangers of food contamination, water pollution, and disease (Srirama et al., 2017). Traditional medicine is an important and historical treatment in many countries, including Iran (Sheidai et al., 2018).

Adulteration means the deliberate replacement or addition of another plant or external material in order to increase the weight, power, or decrease of the cost of the product, generally considered as deliberate action. That forgery could occur due to the lack of knowledge about the primary plant, the similarity in the name, the morphology and the aroma of species associated with low cost plant material, so it should take care of the wrong kinds from the beginning because improper use of medicinal plants can cause irreparable damage to the body (El Beyrouthy and Abi-Rizk, 2013).

One of the obvious examples, in this case, 100 female patients are diagnosed with kidney failure due to the wrong use of Stephania tetrandra S. Moore instead Aristolochia fangchi Y.C.Wu ex L.D.Chow \& S.M.Hwang, due to the similarity in the name and morphology of it in China. Other similar cases can be pointed out to the skin of the Cinnamomum verum J. Presl, which causes poisoning because of mixing with toxic Cinnamomum cassia (L.) J.Presl species (Srirama et al., 2017).

The general method of identification of plants is the use of morphological, anatomical, chemical, and molecular techniques. Therefore, the traditional classification requires the expertise of professionals with professional experience. In some cases, it may be difficult for experts to identify samples without diagnostic parts (Salim Khan et al., 2011; El Beyrouthy and Abi-Rizk, 2013; Ghorbani et al., 2017).

Microscopic mass spectrometry and more recently, DNA barcoding, genomics, proteomics, and metabolomics techniques have been used to examine the correctness or wrong of medicinal plants (Sucher et al., 2008; Ghorbani et al., 2017).

DNA barcoding is a sequence of DNA that can help in rapid and accurate recognition of species. It has been used in the identification of medicinal plants and has been able to detect actual and original products from its fake type (Heubl et al., 2010; Sheidai et al., 2018). These methods provide suitable tools for analyzing the selling markets of medicinal plants, which require precise identification of plant species, such as sample sequences, comparing sequence obtained with sequences recorded in the reference database, and various nucleotide sequence to differentiate the similar species (Sucher et al., 2008; Newmaster et al., 2013).

Identification of medicinal plants on the basis of DNA sequence and multiple and its variation with sister species is currently used in chloroplast DNA (the ribulose-1, 4-bisphosphate carboxylase large subunit gene (rbcL), the ribosomal RNA maturase gene (matK), and trnH-psbA regions) and ITS nuclear DNA (CBOL Plant Working Group, 2009; Hollingsworth et al., 2011).

In Iran, there are around 8,000 species of plants, of which 2300 species are aromatic and medicinal, and the number of 450 species is sold in traditional herbal shops (Sheidai et al., 2018). 
Melissa officinalis L. is one of the medicinal species known as badranjboye in Iran. This species is well known as a medicinal plant and people use it. It is used in a variety of forms such as essential oils, oily extract, oil, and infusion and various properties, including the treatment of stomach with neural origin and disorders. Badranjboye was an essential drug of Avicenna, which has been prescribed for the enhancement of the heart and the expansion of the soul. The use of the plant as an antidepressant continued until the 17th century (Akhlaghi et al., 2001; Miraj et al., 2007; Nasri and Rafieian-Kopaei,2011; Setorki et al., 2013).

In Iran, the genus of Dracocephalum L., HymenocraterFisch. \& C.A.Mey., Nepeta L. and Stachys L. are mistakenly called badranjboye. therefore, it should be noted that by using these plants, it is not expected to produce effects of it. The distinction between plants and plants is that badranjboye has heart - shaped leaves, while Dracocephalum moldavica L. has elongated leaves and a length of $3-5 \mathrm{~cm}$ and $1-5 \mathrm{~cm}$ wide. It is also distinguished from Hymenocrater, which leaves no smell of lemon in the leaves of the leaves (Jamzad, 2012).

Considering that the identification of plants is sometimes not possible from appearance due to its powdered, the objectives of this project can be referred to: 1 - Determining the integrity of medicinal plants in the country's pharmaceutical market and to identify any fraud through molecular approaches 2 - Develop a molecular barcode to identify species Melissa officinalis from other items identified as badranjboye.

\section{Material And Methods}

For DNA barcode, medicinal leaf samples by badranjboye name were collected from 22 traditional herbal shops in eight provinces Iran (Table1). For determine the appropriate parts for the barcodes, the sequences recorded at National Center for Biotechnology Information (NCBI) GenBank (https://www.ncbi.nlm.nih.gov/). for internal transcribed spacer (ITS) and chloroplast region (trnH- psbA, trnL-trnF) of Melissa, Dracocephalum L. and Hymenocrater Fisch. \& C.A.Mey. were first obtained (Table2).

Table1 The locality of medicinal plants as badranjboye.

\begin{tabular}{llll} 
Number & Province & Number & Province \\
\hline 1 & Tehran & 12 & Mazandaran, Babolsar \\
\hline 2 & Tehran & 13 & Mashhad, Neyshabur \\
\hline 3 & Alborz & 14 & Mashhad, Sabzevar \\
\hline 4 & Alborz & 15 & Mashhad, Sabzevar \\
\hline 5 & Alborz & 16 & Mashhad, Sabzevar \\
\hline 6 & Alborz & 17 & Ardabil \\
\hline 7 & Alborz & 18 & Tabriz \\
\hline 8 & Shiraz & 19 & Lorestan \\
\hline 9 & Shiraz & 20 & Lorestan \\
\hline 10 & Shiraz & 21 & Isfahan \\
\hline 11 & Mazandaran, Amol & 22 & Isfahan \\
\hline
\end{tabular}

\subsection{DNA extraction and amplification}

Genomic DNA was extracted using cetyltrimethyl- ammonium bromide (CTAB) with activated charcoal protocol (Koohdar et al., 2019). The quality and quantity of extracted DNA were assessed by running on $0.8 \%$ agarose gel.

Internal transcribed spacer and trnH-psbA region in chloroplast were amplified based Sheidai 2018; Mohebi anabat et al., 2019. The PCR reaction mixture consisted of $20 \mathrm{ng}$ genomic DNA and $3 \mathrm{U}$ of Taq DNA polymerase (Bioron, Germany); $50 \mathrm{mM} \mathrm{KCl;} 10$ 
$\mathrm{mM}$ Tris- $\mathrm{HCl}$ buffer at $\mathrm{pH} ; 81.5 \mathrm{mM} \mathrm{MgCl} 2 ; 0.2 \mathrm{mM}$ of each dNTP (Bioron, Germany); 0.2l $\mathrm{M}$ of each primer in a total volume of 25 pi. DNA amplification was performed on a BIO RAD (T100 Thermal cycler). with the following program: 5 min at 94 C, 35 cycles of $1 \mathrm{~min}$ at $94 \mathrm{C}, 1 \mathrm{~min}$ at $49-58 \mathrm{C}$ (trnH-psbA primers at $50 \mathrm{C}$ and ITS primers at 54C) and $1 \mathrm{~min}$ at $72 \mathrm{C}$ and a final cycle of $7 \mathrm{~min}$ at $72 \mathrm{C}$. The PCR amplified products were separated byelectrophoresis on $2 \%$ agarose gels (Merck). The gels were stained with ethidium bromide and visualized under UV light or silver stained for added sensitivity. Fragment size was estimated by using a 100 base pair (bp) molecular size ladder (Fermentas, Germany).

\subsection{Data analyses}

ITS and chloroplast (trnH-psbA, trnL-F) Sequences obtained of NCBI (Table2) after alignment and curation using molecular evolutionary genetics analysis (MEGA) ver. 7 were analyzed (Kumar et al., 2016). Maximum liklihood, Maximum parsimony, NJ (Neighbor joining) and UPGMA (Unweighted paired group using average) tree were plotted to show delimitation between the genera and their species. After clustering and measuring the distance between Dracocephalum, Hymenocrater and Melissa spices based on ITS, trnH-psbA and trnL-F markers, we concluded that ITS and trnH-psbA are the most appropriate for the Melissa officinalis barcode. Therefore, the Iran market samples were amplified with these markers.

Identification of unknown barcodes from Iran market leaves was basically conducted by Basic Local Alignment Search Tool (BLAST) data with a minimum BLAST cut off of $97 \%$ identity for a top match. These results were verified by clustering and phylogenetic analyses in which we compared the branches of unknown specimens to sequences of reference species. genetic analysis in MEGA v.7 (Kumar et al., 2016).

For barcode gap analysis, two different approaches were used. 1- to compare identify barcodes and differentiating sequences between Melissa officinalis and the potential adulterants as well as to search common and constant sequences in Melissa officinalis that differ with the adulterant plant with aligned sequences. 2- The power of differentiating the locus of studies using a genetic distance method is designed to assess whether the diversity of among the distinct species is indicated without the influence of species and genera diversity. This method is based on the identification of barcoding gap, which means that the number of sequences in species is lower than the species. for this purpose, Kimura 2-parameters genetic distance different sequence differences were used inside and among the congeneric species by molecular evolutionary genetics analysis MEGA v.7 (Kumar et al., 2016). Accordingly, the distance within Melissa officinalis should be less than that of other species of this genus and other genera (Meyer et al., 2008).

\section{Results}

\subsection{Investigation of delimitation between medicinal genera and species using ITS marker}

ITS, trnH-psbA, and trnL-F Sequences (table2) after alignment and curation according to the analysis made under the model were analyzed. In Maximum likelihood plot based on ITS and trnH-psbA Sequences (Fig. 1 and 2), Melissa officinalis samples were separated from Hymenocrater, Dracocephalum and Melissa axillaris (Benth.) Bakh.f. but these genera cannot separate from the othere based on trnL-F Sequences (Fig. 3). Therefore, this region was not suitable for DNA barcoding in Melissa officinalis.

Table2 The spices names and gene bank number of taxa in ITS and cp-DNA studies. 
Spices names and Gene bank numbers of ITS marker

Melissa officinalis

(EU796895.1)

Melissa officinalis

(DQ189090.1)

Melissa officinalis

(MK425905.1)

Melissa officinalis

(DQ667291.1)

Melissa axillaris

(KM886748.1)

Melissa axillaris

(JQ669114.1)

Dracocephalum moldavica L.

(AY506659.1)

Dracocephalum kotschyi Boiss.

(AJ420998.1)

Hymenocrater bituminosus Fisch. \&

C.A. Mey.

(JQ669105.1)

Hymenocrater elegans Bunge. J Essent. Hymenocrater incanus (MH175477.1)

(LC316148.1)

Hymenocrater bituminosus Fisch. \&

C.A.Mey.

(LC316144.1)

Hymenocrater platystegius Rech. f., $\mathrm{H}$.

(LC316140.1)

Hymenocrater calycinus (Boiss.) Benth.
Spices names and Gene bank numbers of trnH-psbA

Melissa axillaris

(KY197901.1)

Melissa officinalis

(KC584964.1)

Melissa officinalis

(HQ902824.1)

Melissa officinalis

(KP643311.1)

Melissa officinalis

(MH781964.1)

Melissa officinalis

(LS999865.1)

Dracocephalum moldavica

(MF371112.1)

Dracocephalum integrifolium

(MF371110.1)

Hymenocrater bituminosus

(MH175478.1)

Melissa axillaris

(KM886646.1)
Spices names and Gene bank numbers of trnL-trnF

Melissa officinalis

(JF301386.1)

Dracocephalum moldavica

(AY506625.1)

Dracocephalum kotschyi

(KX641651.1)

Melissa axillaris

(JQ669051.1)

Hymenocrater platystegius

(LC316173.1)

Hymenocrater bituminosus

(JQ669045.1)

Hymenocrater calycinus

(LC316155.1)

Melissa officinalis

(AJ505529.1) 
(LC316147.1)

Based on Kimura 2-parameters genetic distance in ITS and trnH-psbA regions, there was no genetic distance within Melissa officinalis (0.00), This result revealed the absence of sequence variability within ITS and trnH-psbA sequences within Melissa officinalis (high uniformity). A high value of genetic distance occurred between Melissa officinalis with other spices (Melissa axillar) and genera (Dracocephalum and Hymenocrater) (0.08 to 0.18). Kimura 2-parameters genetic distance based on trnL-F region showed a high value of genetic distance within Melissa officinalis.

Common and specific sequences were examined in the ITS and trnH-psbA genetic regions. We attempted to create barcode gaps between the species and genera studied. Accordingly, in ITS region,6 nucleotides with numbers $(117,131,227,522,650,655)$ were identified as barcode gap for Melissa officinalis and Melissa axillaris while trnH-psbA region could be identified only 2 barcodes to differentiate. Thirty nucleotides were used as a barcode gap for the separation of Melissa genus from Hymenocrater and Dracocephalum in both regions. ITS and trnH-psbA region can be considered as a barcode gap in Melissa officinalis (Figs. 4 and 5). Therefore, for barcoding gap and differentiating between Melissa officinalis with other spices and genera we suggested using ITS and trnH-psbA sequences as barcode gaps.

\subsection{Morphology and odor of the medicinal products}

Morphologically the leaf samples sold in the market were similar to Melissa, Dracocephalum, and Hymenocrater. It was important to note the presence of Boraginaceae and Poaceae family leaves in the collected specimens. 2 samples were powdered and could not be identified by leaf. Based on odor, the samples studied were mostly odorless and occasionally smell of lemon (Table3).

Table3 Medicinal plant products studied, their odor and leaf morphological resemblance.

\begin{tabular}{|c|c|c|c|c|c|c|c|}
\hline NO & Province & Leaf shape & Odor & NO & Province & Leaf shape & Odor \\
\hline 1 & Tehran & Asperugo & Nothing & 12 & $\begin{array}{l}\text { Mazandaran, } \\
\text { Babolsar }\end{array}$ & $\begin{array}{l}\text { Dracocephalum } \\
\text { and Hymenocrater }\end{array}$ & Lemon \\
\hline 2 & Tehran & Asperugo & Nothing & 13 & $\begin{array}{l}\text { Mashhad, } \\
\text { Neyshabur }\end{array}$ & $\begin{array}{l}\text { Dracocephalum } \\
\text { and Hymenocrater }\end{array}$ & Lemon \\
\hline 3 & Alborz & Nothing & Nothing & 14 & $\begin{array}{l}\text { Mashhad, } \\
\text { Sabzevar }\end{array}$ & $\begin{array}{l}\text { Dracocephalum } \\
\text { and Hymenocrater }\end{array}$ & Lemon \\
\hline 4 & Alborz & Asperugo & Nothing & 15 & $\begin{array}{l}\text { Mashhad, } \\
\text { Sabzevar }\end{array}$ & $\begin{array}{l}\text { Dracocephalum } \\
\text { and Hymenocrater }\end{array}$ & Lemon \\
\hline 5 & Alborz & $\begin{array}{l}\text { Dracocephalum } \\
\text { and Hymenocrater }\end{array}$ & Lemon & 16 & $\begin{array}{l}\text { Mashhad, } \\
\text { Sabzevar }\end{array}$ & $\begin{array}{l}\text { Dracocephalum } \\
\text { and Hymenocrater }\end{array}$ & Nothing \\
\hline 6 & Alborz & Nothing & Lemon & 17 & Ardabil & Nothing & Nothing \\
\hline 7 & Alborz & Mellisa and Hymenocrater & Lemon & 18 & Tabriz & Nothing & Nothing \\
\hline 8 & Shiraz & Mellisa and Hymenocrater & Lemon & 19 & Lorestan & Mellisa and Hymenocrater & Lemon \\
\hline 9 & Shiraz & Mellisa and Hymenocrater & Lemon & 20 & Lorestan & Mellisa and Hymenocrater & Lemon \\
\hline 10 & Shiraz & Mellisa and Hymenocrater & Lemon & 21 & Isfahan & $\begin{array}{l}\text { Dracocephalum } \\
\text { and Hymenocrater }\end{array}$ & Lemon \\
\hline 11 & $\begin{array}{l}\text { Mazandaran, } \\
\text { Amol }\end{array}$ & $\begin{array}{l}\text { Dracocephalum } \\
\text { and Hymenocrater }\end{array}$ & Nothing & 22 & Isfahan & $\begin{array}{l}\text { Dracocephalum } \\
\text { and Hymenocrater }\end{array}$ & Lemon \\
\hline
\end{tabular}

Blast results of the market products/samples studied based on ITS and trnH-psbA regions produced similar results; therefore, only ITS results are presented in Table4. The samples sold in the market as badranjboye (Melissa officinalis), showed sequence 
similarity with various species and genera like Asperugo procumbens L. and Mertensia virginica (L.) Pers. ex Link of Boraginaceae family, Trigonella foenum-graecum L. and Melilotus officinalis (L.) Pall. of Fabaceae family, Hymenocrater and Dracocephalum of lamiaceae family. only 7 samples of 22 samples were similar to Melissa officinalis.

Table 4 The BLAST results of the sample products. 


\begin{tabular}{|c|c|c|c|}
\hline Number of Medicinal plant based on Table1 & Blast of species of $\mathrm{NCBI}$ & Accession & Identity \\
\hline \multirow[t]{2}{*}{1} & Asperugo procumbens & JQ388496.1 & $96.57 \%$ \\
\hline & Mertensia virginica & JQ388507.1 & $91.78 \%$ \\
\hline \multirow[t]{2}{*}{2} & Asperugo procumbens & JQ388497.1 & $98.97 \%$ \\
\hline & Mertensia alpina & JQ388507.1 & $94.26 \%$ \\
\hline \multirow[t]{2}{*}{3} & Asperugo procumbens & JQ388496.1 & $99.12 \%$ \\
\hline & Mertensia alpina & JQ388507.1 & $94.69 \%$ \\
\hline \multirow[t]{2}{*}{4} & Asperugo procumbens & JQ388497.1 & $99.56 \%$ \\
\hline & Mertensia alpina & JQ388507.1 & $94.92 \%$ \\
\hline \multirow[t]{5}{*}{5} & Hymenocrater sessilifolius & LC316142.1 & $85.25 \%$ \\
\hline & Hymenocrater calycinus & LC316147.1 & $85.04 \%$ \\
\hline & Hymenocrater bituminosus & LC316144.1 & $85.04 \%$ \\
\hline & Hymenocrater platystegius & LC316140.1 & $85.04 \%$ \\
\hline & Hymenocrater bituminosus & JQ669105.1 & $84.63 \%$ \\
\hline 6 & Melissa officinalis & KJ584249.1 & $100.00 \%$ \\
\hline 7 & Melissa officinalis & AY506650.1 & $98.75 \%$ \\
\hline \multirow[t]{4}{*}{8} & Melissa officinalis & AY506650.1 & $99 \%$ \\
\hline & Melissa officinalis & KJ584249.1 & $98.75 \%$ \\
\hline & Melissa officinalis & EU796895.1 & $96 \%$ \\
\hline & Melissa officinalis & DQ667291.1 & $95 \%$ \\
\hline \multirow[t]{4}{*}{9} & Melissa officinalis & EU796895.1 & $99 \%$ \\
\hline & Melissa officinalis & DQ667291.1 & $96 \%$ \\
\hline & Melissa officinalis & DQ189090.1 & $95 \%$ \\
\hline & Melissa officinalis & JF301353.1 & $95 \%$ \\
\hline \multirow[t]{4}{*}{10} & Melissa officinalis & DQ667291.1 & $99 \%$ \\
\hline & Melissa officinalis & DQ189090.1 & $96 \%$ \\
\hline & Melissa officinalis & JF301353.1 & $95 \%$ \\
\hline & Melissa officinalis & KY072952.1 & $95 \%$ \\
\hline \multirow[t]{4}{*}{11} & Hymenocrater bituminosus & LC316144.1 & $92 \%$ \\
\hline & Hymenocrater platystegius & LC316140.1 & $92 \%$ \\
\hline & Hymenocrater bituminosus & JQ669105.1 & $94 \%$ \\
\hline & Hymenocrater sessilifolius & LC316142.1 & $92 \%$ \\
\hline \multirow[t]{3}{*}{12} & Hymenocrater platystegius & LC316140.1 & $92 \%$ \\
\hline & Hymenocrater bituminosus & JQ669105.1 & $94 \%$ \\
\hline & Hymenocrater sessilifolius & LC316142.1 & $92 \%$ \\
\hline
\end{tabular}

Page 8/16 


\begin{tabular}{|c|c|c|c|}
\hline & Hymenocrater calycinus & LC316147.1 & $92 \%$ \\
\hline \multirow[t]{3}{*}{13} & Dracocephalum moldavica & AY506659.1 & $95.45 \%$ \\
\hline & Dracocephalum bullatum & JQ669096.1 & $95.45 \%$ \\
\hline & Dracocephalum parviflorum & JQ669097.1 & $95.33 \%$ \\
\hline \multirow[t]{4}{*}{14} & Hymenocrater calycinus & LC316147.1 & $85.04 \%$ \\
\hline & Hymenocrater bituminosus & LC316144.1 & $85.04 \%$ \\
\hline & Hymenocrater platystegius & LC316140.1 & $85.04 \%$ \\
\hline & Hymenocrater bituminosus & JQ669105.1 & $84.63 \%$ \\
\hline \multirow[t]{4}{*}{15} & Hymenocrater sessilifolius & LC316142.1 & $92 \%$ \\
\hline & Hymenocrater calycinus & LC316147.1 & $92 \%$ \\
\hline & Hymenocrater bituminosus & LC316144.1 & $92 \%$ \\
\hline & Hymenocrater platystegius & LC316140.1 & $92 \%$ \\
\hline \multirow[t]{4}{*}{16} & Dracocephalum moldavica & AY506659.1 & $91 \%$ \\
\hline & Dracocephalum moldavica & MH710906.1 & $90 \%$ \\
\hline & Dracocephalum bullatum & JQ669096.1 & $90 \%$ \\
\hline & Dracocephalum kotschyi & AJ420998.1 & $90 \%$ \\
\hline \multirow[t]{2}{*}{17} & Trigonella foenum-graecum & DQ312196.1 & $99.72 \%$ \\
\hline & Melilotus officinalis & DQ311985.1 & $96.47 \%$ \\
\hline \multirow[t]{2}{*}{18} & Trigonella foenum-graecum & DQ312196.1 & $99.72 \%$ \\
\hline & Melilotus officinalis & DQ311985.1 & $96.47 \%$ \\
\hline \multirow[t]{4}{*}{19} & Melissa officinalis & KY072952.1 & $98 \%$ \\
\hline & Melissa officinalis & AY506650.1 & $97 \%$ \\
\hline & Melissa axillaris & JQ669114.1 & $97 \%$ \\
\hline & Melissa axillaris & KM886748.1 & $96 \%$ \\
\hline \multirow[t]{4}{*}{20} & Melissa officinalis & KY072952.1 & $98 \%$ \\
\hline & Melissa officinalis & AY 506650.1 & $97 \%$ \\
\hline & Melissa axillaris & JQ669114.1 & $97 \%$ \\
\hline & Melissa axillaris & KM886748.1 & $96 \%$ \\
\hline \multirow[t]{4}{*}{21} & Hymenocrater calycinus & LC316147.1 & $92 \%$ \\
\hline & Hymenocrater bituminosus & LC316144.1 & $92 \%$ \\
\hline & Hymenocrater platystegius & LC316140.1 & $92 \%$ \\
\hline & Hymenocrater bituminosus & JQ669105.1 & $90 \%$ \\
\hline \multirow[t]{4}{*}{22} & Hymenocrater calycinus & LC316147.1 & $92 \%$ \\
\hline & Hymenocrater bituminosus & LC316144.1 & $92 \%$ \\
\hline & Hymenocrater platystegius & LC316140.1 & $92 \%$ \\
\hline & Hymenocrater bituminosus & JQ669105.1 & $90 \%$ \\
\hline
\end{tabular}

Page 9/16 


\subsection{Genetic distance results within and between market samples and the reference species based on ITS and trnH-psbA regions}

Kimura 2-parameters genetic distance determined both within the studied market samples and between the samples and the reference species based on ITS and trnH-psbA regions was provided. According to these results, the market samples have high genetic distance with each other, for example the genetic distance between samples of Shiraz (No 2 based on table1) and samples of Isfahan and Ardabil (No 2 based on table1) were 0.6 to 0.10 , while the distance between them with the samples with the highest percentage of similarity in the blast (Table4) is the most similar (0.00-0.02). This gap indicates that the samples are not identical in the market and the fraud in their sales.

\subsection{Phylogenetic analyses of the market products/samples studied based on ITS and trnH-psbA regions}

Phylogenetic analyses of the market products/samples studied based on ITS and trnH-psbA regions were done. Different methods like Maximum parsimony, Maximum likelihood and UPGMA produced similar results by MEGA ver.7 software; therefore, only Maximum likelihood plot is presented here (Figs. 6 and7). In this plot, the market samples were placed next to the samples with the highest percentage of similarity in the blast (Table4). For example, samples 1, 2, 3 and 4 that showed the most similarity to Asperugo procumbens and Mertensia virginica were placed next to them (Table4). These result warns us about adulteration in this medicinal species marketing.

\section{Discussion}

In the current century, people face various kinds of healthy behaviors such as food risks, air pollution, diseases, and so on. Humans rely on different types of treatments to get healthier and better quality of life. Traditional medicine, mainly based on plants, is considered as an important and historical treatment in many countries. Therefore, to maintain safe and real marketing of medicinal plants and consumer products, the maximum care and supervision should be carried out. It is important to use the best and most effective modern techniques in this regard. For this purpose, the Barcoding and molecular techniques that are now available must be used.

Accurate and effective identification of gene sequences may vary in different plant species and should be investigated separately in each case. For example, Laiou et al. (2013) investigated " core barcode " for land plants (rbcL, matK, and trnH psbA) in 24 taxa. They sought to identify the right species based on sequences, presence of DNA, gaps and differentiation. The highest genetic diversity was observed in the trnH - psbA area; however, DNA barcoding was found in most cases using a sequence divergence in such a species. In general, species identification was successfully performed by $66.7 \%$. Armenise et al. (2012) also reported successful barcoding in Pinaceae with rbcL $+\mathrm{trnH}-\mathrm{psbA}$.

Medicinal plants adulteration has been identified throughout the world. For example, Newmaster et al. (2013) studied the plant product of a firm according to the probability of cheating using the method (rbcL + ITS2) and succeeded in improving DNA barcode in most plant products (91\%)and all leaf samples (100\%)with a resolution of $95 \%$ species. According to the reports, most of the products examined (59\%) had DNA barcode of plant species that were not marked on the tag. Almost half of the products (48\%)were confirmed by the study.

Shidia et al. 2018, Using ITS marker revealed that kakoti (ziziphora) is contaminated or adulterated with Thymus spices in Iran. in the other study they used trnH-psbA region to separate Iranian saffron from the world's saffron (Mohebi anabat et al., 2019).

In Iran, badranjboye is one of the medicinal plants sold throughout the country. This study shows that this important product is introduced with the genera Dracocephalum and Hymenocrater as badranjboye. The results of morphology, odor, BLAST, phylogenetic tree, genetic distance, and barcode gap showed that at least 5 genera of Hymenocrater, Dracocephalum, Asperugo, Mertensia, Trigonella, and Melilotus were sold in the 22 markets studied as Melissa Officinalis which could have very negative effects on human health. 


\section{Conclusion}

Due to the medicinal value of Melissa officinalis, this spices is sold in Iranian markets, and because of similarity of the name and increasing the weight of the product some genus like Dracocephalum, Hymnocrater, Asperugo, Mertensia, Trigonella, and Melilotus have been sold instead. Results of the present study identified adulteration in Melissa officinalis products in Iranian market and that ITS and trnH-psbA sequences are efficient molecular marker for barcoding of this medicinally important plant. This is the first report on Melissa officinalis.

\section{Abbreviations}

ITS: Internal transcribed spacer

PsbA-trnH: psbA-trnH intergenic spacer

DNA barcoding: Deoxyribonucleic acid barcoding

Cp-DNA: Chloroplast DNA

CTAB: cetyltrimethyl- ammonium bromide $3 \mathrm{U}$

mM: Mill molar

dNTP: Deoxynucleoside triphosphate

NCBI: National Center for Biotechnology Information

MEGA: Molecular evolutionary genetics analysis

UPGMA: Unweighted paired group using average

BLAST: Basic Local Alignment Search Tool

rbcl: Ribulose bisphosphate carboxylase

\section{Declarations}

-Ethics approval and consent to participate: "Not applicable"

-Consent for publication: "Not applicable"

-Availability of data and material: Plant materials were stored in Shahid beheshti university Herbarium.

-Competing interests: All authors have no conflict of interest

-Funding: "Not applicable"

-Authors' contributions: Masood Sheidai: Conceptualization of the project: Fahimeh Koohdar data collection and lab work

-Acknowledgements: "Not applicable"

\section{References}

1. Akhlaghi, M., Shabanian, G., Rafieian-Kopaei, M., Parvin, N., Saadat, M., Akhlaghi, M., 2011. Citrus aurantium blossom and preoperative anxiety. Rev. Bras. Anestesiol. 61,702-712. 
2. Armenise, L., Simeone, M.C., Piredda, R., Schirone, B., 2012. Validation of DNA barcoding as an efficient tool for taxon identification and detection of species diversity in Italian conifers. Eur. J. For. Res. 131, 1337-1353. https://doi.org/10.1007/s10342-010-0420-1.

3. El Beyrouthy, M., Abi-Rizk, A., 2013. DNA fingerprinting: the new trend in fighting the adulteration of commercialized and cultivated medicinal plants. Adv. Crop. Sci. Technol. 1, e107. https://doi.org/10.4172/2329-8863.1000e107

4. Ghorbani, A., Saeedi, Y., de Boer, H.J., 2017. Unidentifiable by morphology: DNA barcoding

5. of plant material in local markets in Iran. PLoS One. 12, e0175722. https:// doi.org/10.1371/journal.pone.0175722.

6. Group, C.P.W., Hollingsworth, P.M., Forrest, L.L., Spouge, J.L., Hajibabaei, M., Ratnasingham, S., van der Bank, M., Chase, M.W., Cowan, R.S., Erickson, D.L., 2009. A DNA barcode for land plants. Proc. Natl. Acad. Sci. 106, 12794-12797. https://doi. org/10.1073/pnas.0905845106.

7. Heubl, G., 2010. New aspects of DNA-based authentication of Chinese medicinal plants by molecular biological techniques. Planta. Med. 76, 1963-1974. https://doi.org/10. 1055/s-0030-1250519.

8. Hollingsworth, P.M., Graham, S.W., Little, D.P., 2011. Choosing and using a plant DNA barcode. PLoS One. 6, e19254. https://doi.org/10.1371/journal.pone.0019254.

9. Jamzad, Z., (2012). Dracocephalum L., Hymnocrater, Melissa. In Assadi M, Maassoumi AA, Mozaffarian M, ed., Flora of Iran, Research Institute of Forests and Rangelands Press, Tehran, Iran, 424-444.

10. Koohdar, F., Sheidai, M., 2019. Molecular investigation in few spices of Dacocephalum in Iran: Species relationship, reticulation and divergence time. IND. CROP. PROD. 141, 111758.

11. Kumar, S., Stecher, G., Tamura, K., 2016. MEGA7: molecular evolutionary genetics analysis version 7.0 for bigger datasets. Mol. Biol. Evol. 33, 1870-1874.

12. Laiou, A., Mandolini, L.A., Piredda, R., Bellarosa, R., Simeone, M.C., 2013. DNA barcoding as a complementary tool for conservation and valorisation of forest resources. ZooKeys. 365, 197-213. https://doi.org/10.3897/zookeys.365.5670.

13. Meyer, R., Zhang, G.Y., Ali, F., 2008. The use of mean instead of smallest interspecific distances exaggerate the size of the "barcoding gap" and leads to misidentification. Syst. Biol. 57, 809-813. https://doi.org/10.1080/10635150802406343.

14. Miraj S, Kopaei R, Kiani S., 2007.Melissa officinalis L: A Review Study with an Antioxidant Prospective. Evid. Based. Complement. Alternat. Med. 22(3), 385-394.

15. Nasri, H., Rafieian-Kopaei, M., 2013. Oxidative stress and aging prevention. Int. J. Prev. Med. 4,1101-1102.

16. Newmaster, S.G., Grguric, M., Shanmughanandhan, D., Ramalingam, S., Ragupathy, S., 2013. DNA barcoding detects contamination and substitution in North American herbal products. BMC Med. 11, 222. https://doi.org/10.1186/1741-701511-222.

17. Srirama, R., Santhosh Kumar, J.U., Seethapathy, G.S., Newmaster, S.G., Ragupathy, S.R., Ganeshaiah, K.N., Shaanker, R.U., Ravikanth, G., 2017. Species adulteration in the herbal trade: causes, consequences and mitigation. Drug. Saf. 40, 651-661. https:// doi.org/10.1007/s40264-017-0527-0.

18. Sheidai, M., Tabaripour, R., Talebi, S.M., Noormohammadi, Z., KoohdarF., 2019.Adulteration in medicinally important plant species of Ziziphora in Iran market: DNA barcoding approach. IND. CROP. PROD. 130, 627-633.

19. Salim Khan, S., Mirza, K.J., Al-Qurainy, F., Zainul Abdin, M., 2011. Authentication of the medicinal plant Senna angustifolia by RAPD profiling. Saudi J. Biol. Sci. 18, 287-292. https://doi.org/10.1016/j.sjbs.2011.03.001.

20. Sucher, N.J., Carles, M.C., 2008. Genome-based approaches to the authentication of medicinal plants. Planta. Med. 74, 603623. https://doi.org/10.1055/s-2008- 1074517.

21. Setorki, M., Rafieian-Kopaei, M., Merikhi, A., 2013. Suppressive impact of Anethum graveolens consumption on biochemical risk factors of atherosclerosis in hypercholesterolemic rabbits. IJPM. 4, 889-895.

\section{Figures}




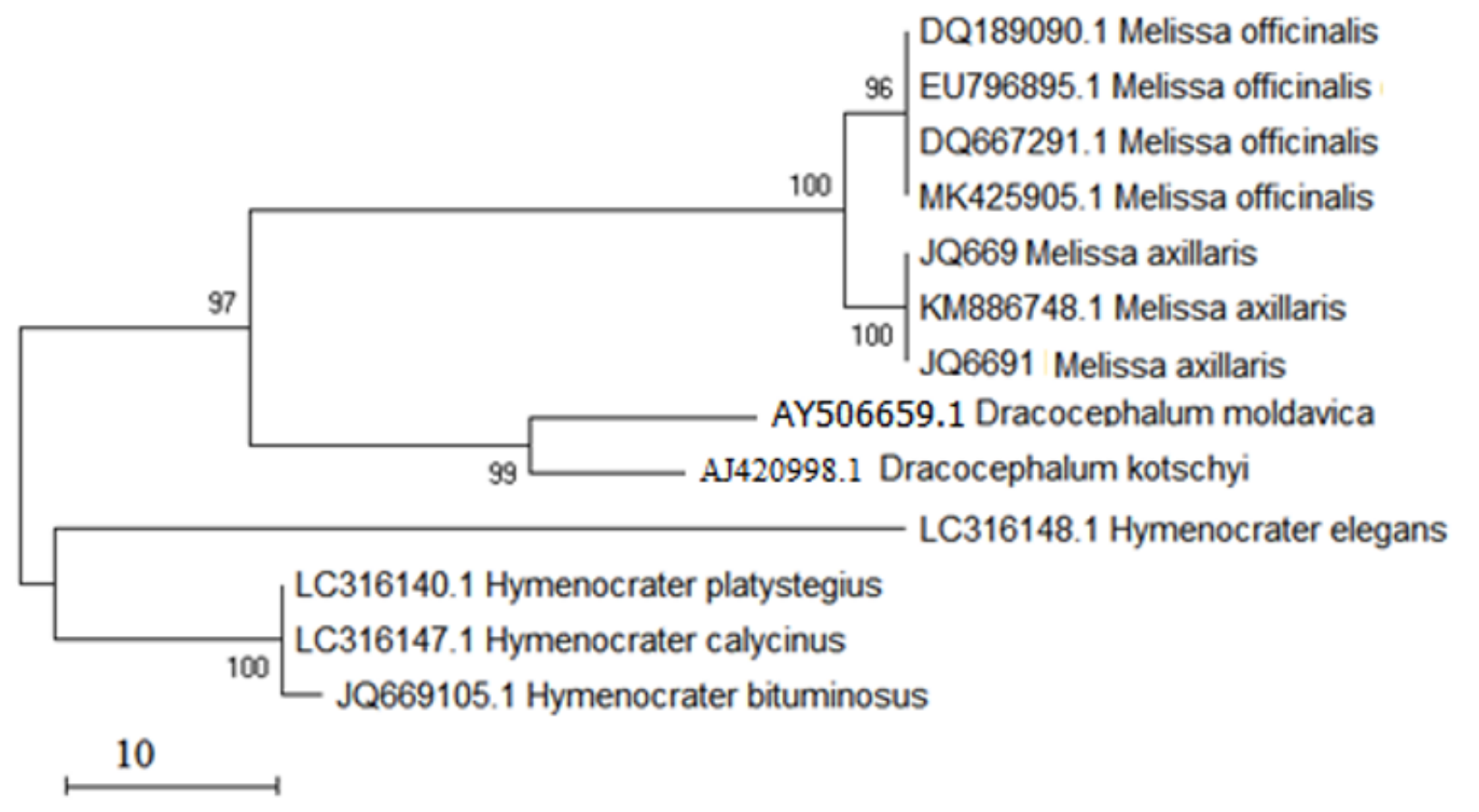

Figure 1

Maximum likelihood phylogenetic tree of NCBI taxa based on ITS Sequences.

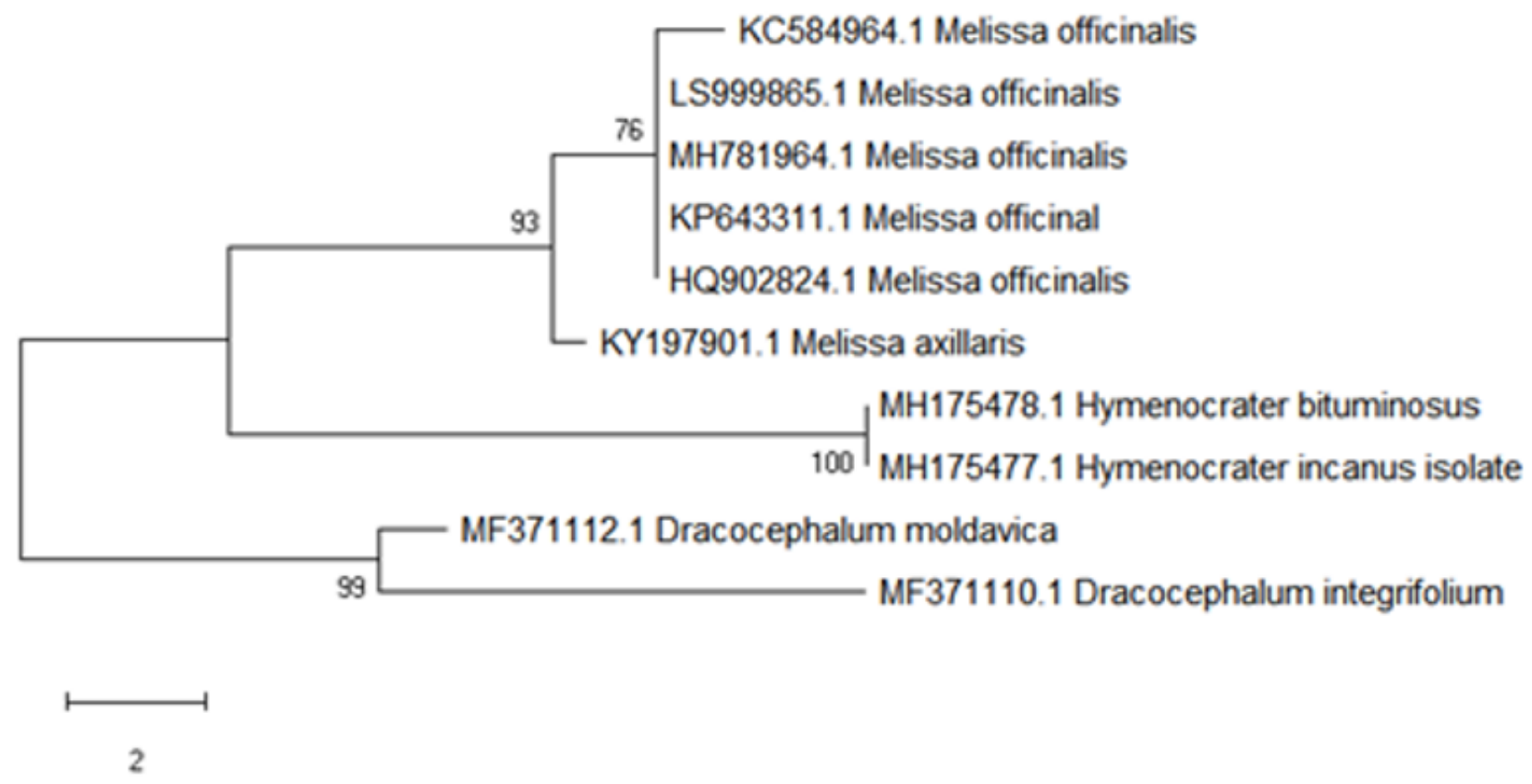

Figure 2

Maximum likelihood phylogenetic tree of NCBI taxa based on trnH-psbA Sequences. 


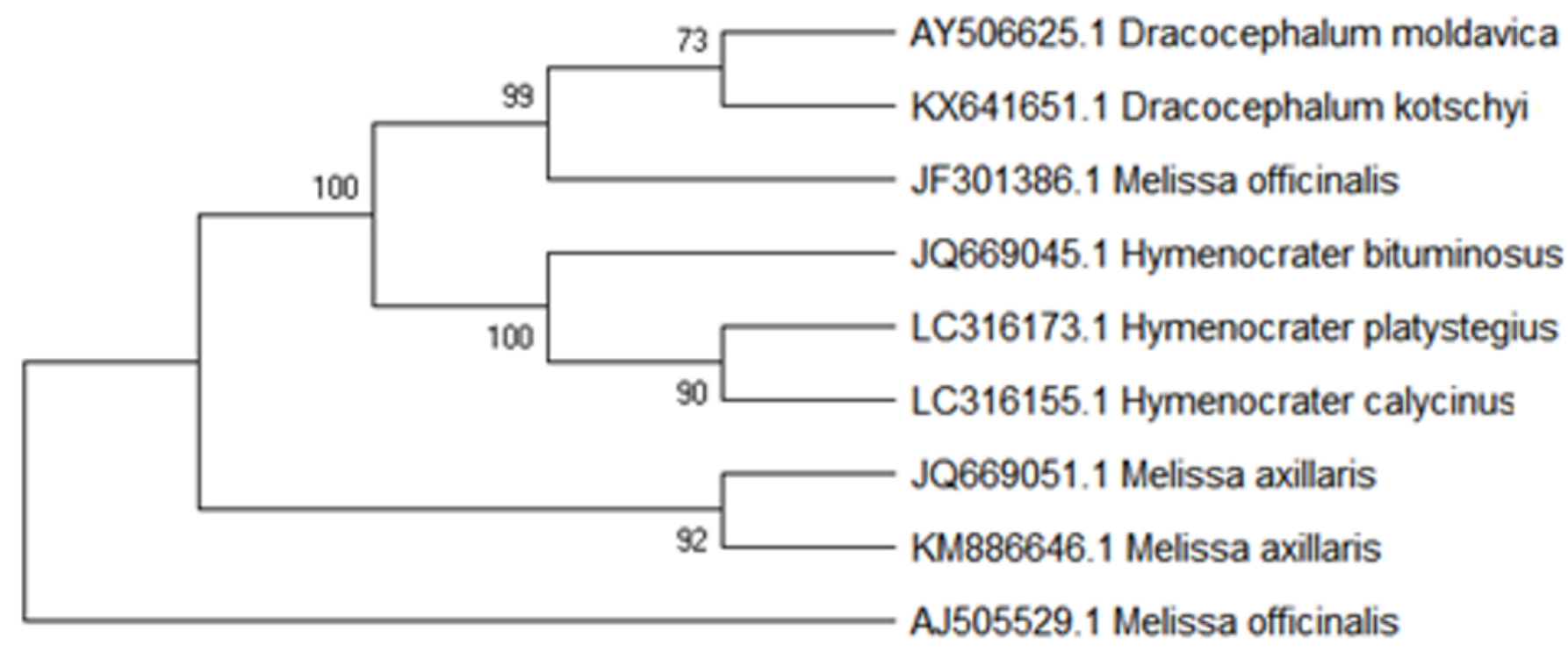

Figure 3

Maximum likelihood phylogenetic tree of NCBI taxa based on ITS trnL-F Sequences.

1 GCAGACCGCGAACACGTGTTTAACTCCTGCCGGCGTCTCCCTCGGTCACGTCGTGCGGACTAACGAACCC 2 GCAGACCGCGAACACGTGTTTAACTCCTGCCGGCGTCTCCCTCGGTCACGTCGTGCGGACTAACGAACCC 3 OCAGACCOCGAACACGTGTTTAACTCCTOCCGOCOTCTCCCTCOGTCACOTCGTGCGGACTAACGAACCC

4 OCAGACCOCOAACACOTGTTTAACTCCTOCCOOCOTCTCCCTCOGTCACOTCOTOCOGACTAACGAACCC

5 GCAGACCOCGAACACOTGTTTAACTCCTOCCGGCOTCTCCCTCOGTCACOTCGTOCGGACTAACGAACCC

6 GCAGACCGCGAACACGTGTTTAACTCCTGCCGGCGTCTCCCTCGGTCACGTCGTGCGGACTAACGAACCC

7 GCAGACC GCGAACACGTGTTTAACTCCTOCCGGCGTCTCCCTCGGTCACGTCGTGCGGACTAACGAACCC

8 OCAGACCOCGAACACGTTAACAACCCCCOCCOOCOCCTCCTCCOGACACOCCOTOCOOGCTAACOAACCC

9 OCAOACCOCOAACACOTTAACAACCCCCOCCOOCOCCTCCTCCOOACACOCCOTOCOOOCTAACOAACCC

10 OCAGACC GC GAACACGTTAACAACCCCCOCCGGCOCCTCCTCCGGAAAC OCCGTOCOGGCTAACGAACCC

11 GC AGACCGCGAACACGAAAACAACCCTTACCGGCGCCTCCCTCGGACACGCCGTGCAGGCTAACGAACCC 12 GCAGACCGCGAACCCGTGCATAACCCCCGCGGGCGTATCCCTTGGCGGCGTCGTGCGGGCTAACCAACCC

13 OCAGACCOCGAACCCOTOCATAACCCCCOCTOGCOTGTCCCTCOOCOOCOTCOTOCGOGCTAACGAACCC

\section{Figure 4}

Barcode gaps in ITS sequences of Melissa officinalis (The numbers are according to Table 1).

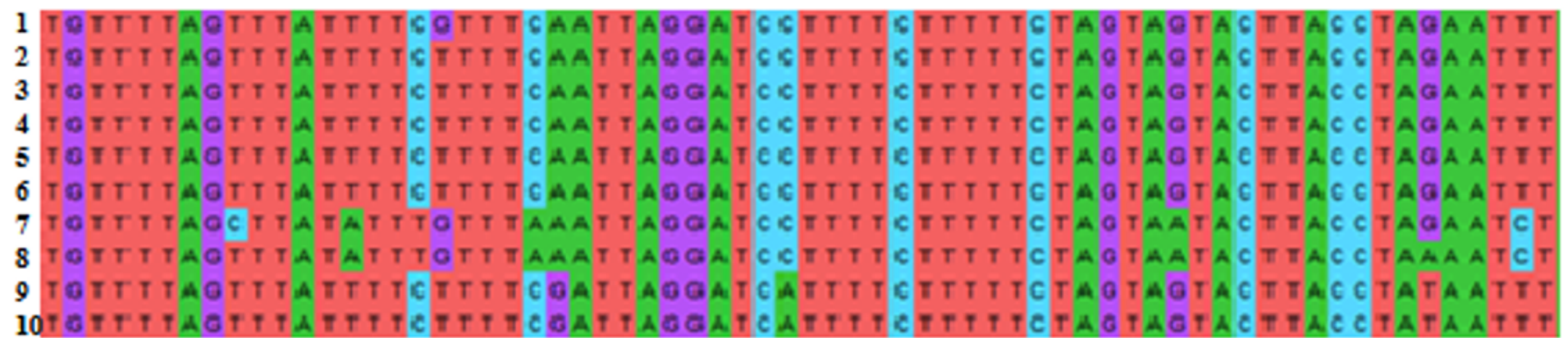

\section{Figure 5}

Barcode gaps in trnH-psbA sequences of Melissa officinalis (The numbers are according to Table 1). 


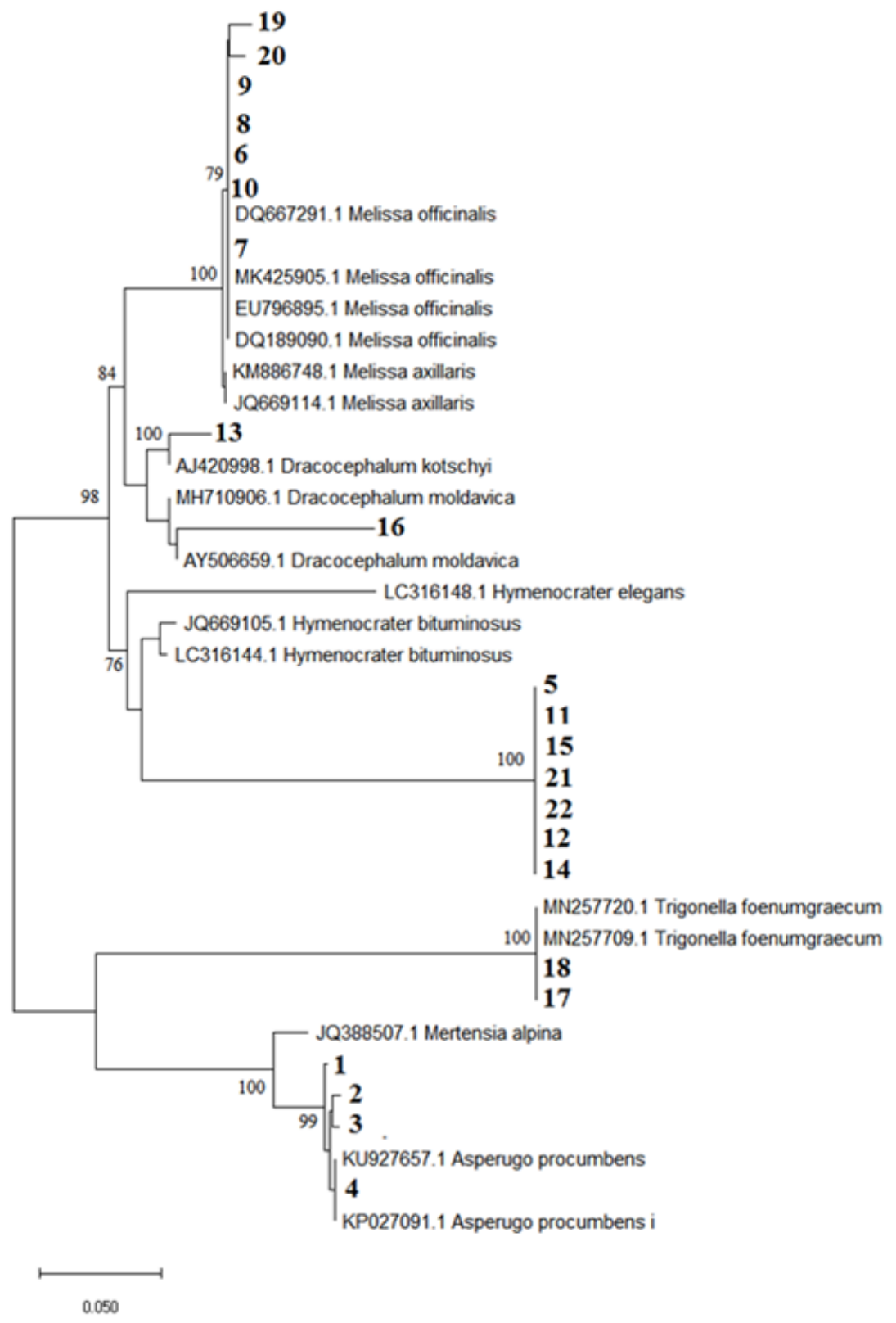

\section{Figure 6}

Maximum likelihood tree of the studied market products (1 to 22 based on table1) and reference species identified by BLAST query, based on ITS sequences. (Numbers above branches are bootstrap value). 


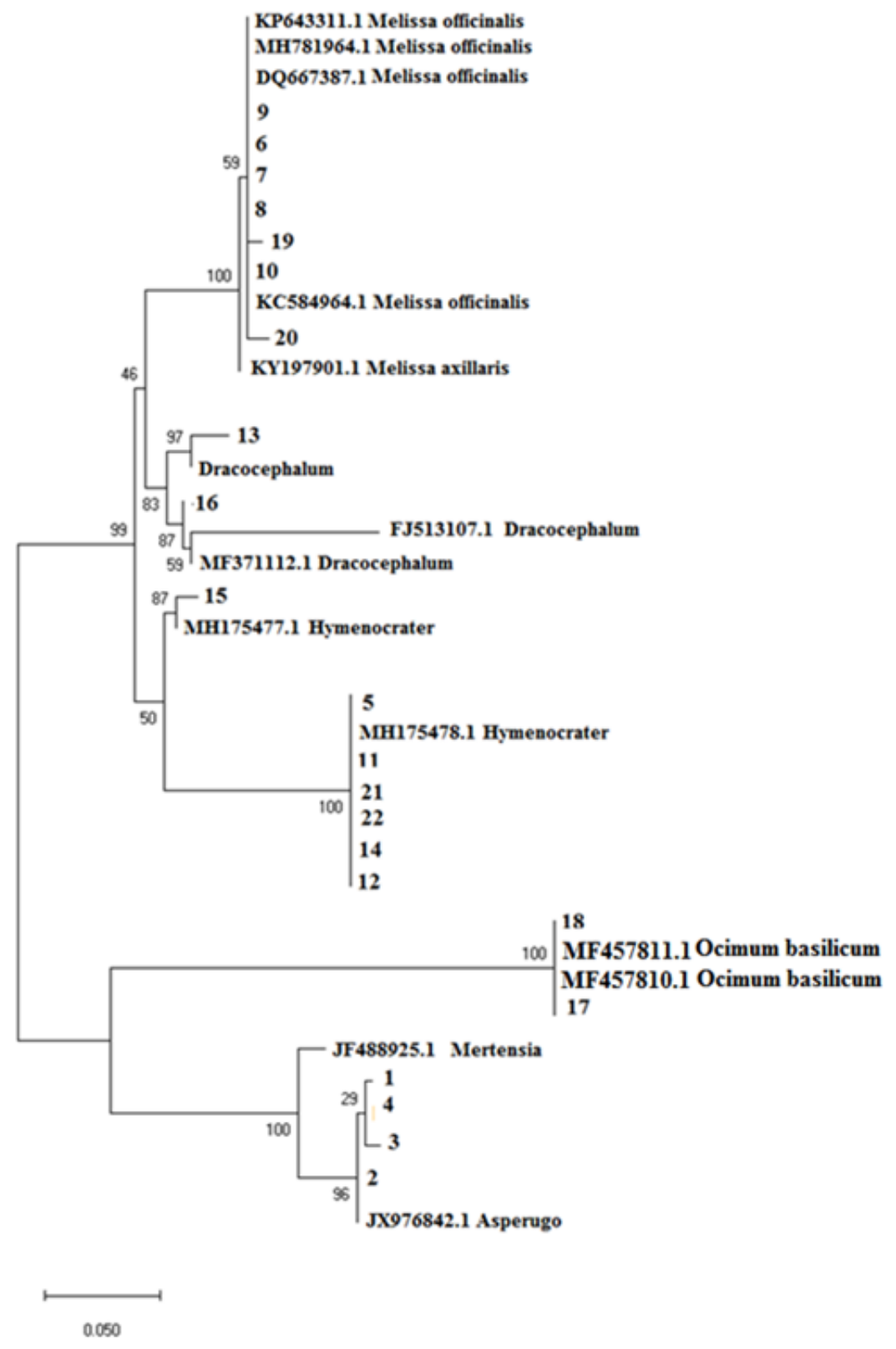

Figure 7

Maximum likelihood tree of the studied market products (1to 22 based on table1) and reference species identified by BLAST query, based on trnH-psbA sequences. (Numbers above branches are bootstrap value). 